\title{
Business families in Southern Patagonia: from the end of the 19th Century to the first decades of 20th century
}

\begin{abstract}
The groups of settlers who arrived in Punta Arenas in Southern Patagonia in the second half of the 19th century, established the trade in hunting products, leather and exotic feathers. They organized the first companies as trading houses between individuals and friends. The capital accumulation of these immigrants promoted take-off and productive control based on external trade routes, an evidence of prior connections abroad. From 1881, the multiplication of some family companies boosted out controlling branches and suppliers of value productive chains through different association to foreign groups encouraged by the offer of land concessions. Partnership by friendship and family also added anonymous societies with a shareholder scheme including family members. The major article's goal is to analyze first family business in this context, through a genealogy business approach. Theoretical concepts and method used here include debates of economic history and entrepreneurial history focused on family business. The core is social and commercial structures for understanding the family continuity, and also business survival in specific contexts. We elaborate three intertwined commercial and family genealogies that worked first in Punta Arenas before 1908 and later in Argentina. And, we analyze strategies by family members of second and third generations achieved for survival, and configuration of the Braun-Menéndez Behety business family. We relate some findings to the connections between Punta Arenas economy and European capitalism; interregional connections; the family as a sociocultural dimension in entrepreneurship; management innovations in rural contexts and the pathways followed to establish the firsts mother-firms in Austral Patagonian Area.
\end{abstract}

Keywords: Businessmen; Patagonia; Family business; Mother-firms; Business genealogies

Corresponding author: e-mail: almaraz@ colef.mx

Received 17 October 2019 - Accepted 1 April 2020

This is an Open Access article distributed under the terms of the Creative Commons Attribution-Non-Commercial-No Derivatives License (http://creativecommons.org/licenses/by-nc-nd/4.0/), which permits non-comercial re-use and distribution, provided the original work is properly cited, and is not altered or transformed in any way. 


\section{Introduction}

Business groups were established in Argentine Patagonia to lead regional development, based on the diversity in political, economic and social strategic activities and social alliances, including those of family nature. This article analyzes the origin, development and expansion of the family business in Punta Arenas, a port locality, through the first companies established in Strait of Magellan (Chile) and the Argentine Patagonia. With a simple example of family and non-family investments, we will see how a small group ventured into the most varied activities at the regional level until it led to a national emporium of warehouses. The following questions lead the research: What elements made possible the origin of family businesses in the Patagonian region between 1868 and 1908? How were the family businesses of the Braun and Menéndez Behety strengthened since the commercial merger of 1908? And what elements they arranged for a successful first generational succession?

We found our theoretical and methodological basis on the history of business. The assumption is that some groups of businessmen in peripheral regions such as Argentine Patagonia had different institutional support to settle in the area. Besides the concessions that allowed productive and commercial takeoff, is necessary to talk about the important group of settlers and businessmen who arrived in the second half of the 19th century and how they developed the first productive activities to sustain the capital accumulation. The second moment came with livestock and the production processes, altering with that the local productive organization. The durability of some first companies and the continuity of families depended on the rapid participation of members of the second generation, and the marriage, exports and control of value chains in Punta Arenas. Therefore, adaptability depends on the parental structure and personal relationships with representatives of the governments of Chile and Argentina. The 
third generation exemplifies the victory of family businesses successions whose members implemented internal specialization-diversification strategies associated with a familycontrolled corporate government. An important element of these early stages was the rise of one of the most important family companies, La Anónima, which remains in force until today in south of Argentina.

Our findings are that the organization carried out by the first groups of European immigrants established in the Strait of Magellan reflects the abilities to visualize and guide regional productive development trough commercial alliances at national and international levels; we must see the land concessions as a key to increase foreign capital stock and the global connections; a simultaneous impulse of local branches and global markets to make possible the control of local productive chains with a few number of suppliers; a high specialization and innovation in livestock in early 20th century familiarly controlled; an entrepreneur dynamic to forming limited partnership, collective business, specifically family business, organized as anonymous societies and combined with informal commercial agreements to reduce transaction costs. This article concludes in the 1930s when generational relay from third to fourth generation of business families occurs. This confirmed the importance of social and parental structure for continuity and perdurability of business despite the conditions in communication channels, population and a changing political context.

\section{Business and family}

The complexity of family ventures and their continuity over time has been studied from unique approaches. The relevance to identify, characterize and analyze businesses that have been controlled by family groups has been discussed in the last decade by Fernández and Lluch, (2015, 19-21), and Fernández-Roca and Gutiérrez (2017); these authors focused on European 
and Latin American cases to debate organizational structures, management and internationalization of family business. In Latin America, studies on the presence and continuity of family in business remain an exercise in construction. Barbero and Lluch $(2015,220)$, have discussed "family capitalism" where the strategic is: ownership by at least two members of one family, at least two family members in the board of directors, members of over one generation controlling property rights, and the companies managed and controlled by original families. However; the heterogeneity of family businesses and trajectories in Latin America (LATAM ahead), implies unique ways and origins that led to theoretical and methodological challenges. To historians studying Latin American companies is essential to move forward definitions allowing understand the configuration of family business, business family and business group. It is necessary to highlight the territorial and historical contexts in the analysis of changes and perdurability of family business. Cerutti $(2015,152)$, recognizes the overlap between business family and business group, pointing out guide-companies (mother-firm) that born and endure linked to business families and contribute to business development and dynamic of specific economic spaces. We study the family business structures evolution. To Cerutti (2015), nuclear families articulate with others to control businesses and generations. The author's perspective is based on the regional and historical dimension of business and parental ties.

Other studies focused families, their early ventures, and family management. Here, the parental structure of companies and its continuity are the unit of analysis. The success or failure of family businesses does not directly associate the configuration of business families, but the continuity of family's networks and transmission of business and knowledge to successors can provoke accumulation of capital and new business (Almaraz 2018, 82-85). This approach uses as control variables the number of generations and businesses created by successors. 
Considering structures of family businesses and business networks understanding the business family configuration, and also like Barbero and Cerutti, starting when two or more generations exist. A constant concern to Almaraz is the configuration of business families in late capitalism of Latin America (Almaraz and Serrano 2016), and how foreign business groups and modern firms overcame, joined and / or changed the native business groups if there was. This work added discussions about Latin family groups, specifically to Argentine approaches where major of family over the non-family firms has evidenced by Barbero and Lluch. ${ }^{1}$ This work also has proposed to adjust the balance around of heterogeneity of family businesses and avoid assumptions about their inevitable failure in Argentina. The theoretical justification took a major step in the historical analysis of economic, and social structures in Latin America.

The family is a structure that allows facing risks. When considering on the one hand, the principles of Veblen's institutional economic theory we are recovering the notion of human action as an economic activity that transforms and evolves by being influenced by structures of social meanings and behaviors (Veblen 1965; Figueiras and Morero 2013). Therefore, we assume that a family business represents a social and economic structure that is organized and culturally transformed. We consider that institutions and their evolution affect the behavior and performance of family businesses as North proposes from the New Institutional Economy (1990), then they are changing in part respond to institutional scope. And also, we assume that in family businesses there are transaction costs that are not contractual or commercial (untraded), permitting them to survive. Then should study in the long run to specify its features and influence in the business perdurability.

\footnotetext{
${ }^{1}$ To these authors between 1918 and 2010, family firms outperformed non-family firms in the largest Argentine companies' group, participation percentages ranging between $60 \%$ and $80 \%$ (Barbero and Lluch 2015, 242). López (2011) also analyze Argentine firms focusing in agribusiness sector.
} 


\section{I.1. Conceptual bases and methodology}

We base our analysis theoretical basis of Veblen's economic institutionalism and some North's ideas about uncommercial transaction costs applied to the study of the family business following the next categories. Ethnic business origin, family business structure as a core of social links, ${ }^{2}$ relational capital, family business extension, family corporate governance and generational succession, and institutional scope. These concepts proposed to analyze the continuity of social structure and business perdurability.

The study focused in first on the configuration of initial businesses in the Patagonian area when produced the settlements. It's continued with a long-run observation of businesses to rebuild business genealogies family ties linked that. The methods used were biographical and historiographical following the general perspective of entrepreneurial historians (Gilbert 2003 and 2009; Fernández and Lluch 2015; Cerutti 2015; Moyano 2015; Almaraz and Serrano 2016), and also making a triangulation of facts of individuals and structural to understand institutional conditions in family and land legislation levels. The primary and secondary sources were biographies, public registers, directories, newsletters and yearbooks, personal letters, and specialized bibliography.

\section{The scenario of Argentine Patagonia: Santa Cruz and Tierra del Fuego.}

The study of business groups begins when production networks established, but it is rare to rethink them from the early stages when they emerge. In the Austral area of Patagonia emerges in 1868 as a budding economic space when arrived foreign settlers to implement business

\footnotetext{
${ }^{2}$ Regarding family business structure, we following the next classification: i) nuclear family businesses whose shareholder structure is only direct parental ties, ii) extended family businesses where shareholders have direct and indirect parental ties, and iii) Composite family businesses where core group of shareholders is a family but it includes partners who have no parental ties (Almaraz 2018).
} 
activities. The "productive network", as defined by Cerutti $(2015,154)$, at Patagonian area must understand since it began the first stage. In this section we show the coming of some settlers and how they created the former business in this region.

Historical studies on peripheral societies and poor industrialization such as Chile and Argentina in the middle of the19th Century, argue that expansion of several Chilean economic sectors towards Argentine Patagonia presented at least until the 1920s, and others show that was until 1930s-1940s (Martinic 2001a). And until a few years ago some others findings achieved by researchers of Argentine economic historians affirmed as an indisputable fact that set of Patagonian territories had incorporated into national and international economic system with exclusive Atlantic orientation through raising of sheep and get-selling of wool as activities that displaced from the Pampas plain due boom in cereals and recovery of beef. However, beyond territorial limits -provincial and / or national-, becomes evident links with outside markets businessmen (Bandieri 2001 and 2013). The business association of these agents represented multiple forms of capital accumulation and linkages with investors and shareholders from other countries. Had persisted to affirm of an "autarkic region" (Martinic 1972, 1975 and 1976; Barbería 1991 and 1995) integrated by Santa Cruz and Tierra del Fuego, accepting that the economy was significantly to Chilean area of Magallanes and its Capital city Punta Arenas because of production of sheep and wool. Hence, must be nuanced these limitations and inaccuracies lighting the many international business contacts founded and the wide range of productive activities during and after the largest stage of land concessions. This article focused to recognize the imprint of first settlers without ignoring that its abrupt arrival generated deep conflicts with the native communities. 


\section{II.1. Institution of land grants and arrival of foreign groups}

Chilean government promoted new settlers at the end of the 1860 s. The border treaty between Argentina and Chile (signed in 1881) and the creation of National Territories of Santa Cruz and Tierra del Fuego (in 1884) were foundations to new measures and to promote the distribution of expropriated land to indigenous communities and to register the first Magellan settlers in southern Patagonia (Bandieri 2005; Bandieri and Blanco 2009; Bandieri 2018). Specifically, in the Carlos María Moyano government (1884-1887) contacted buyers in Santa Cruz to complete the leases and / or buy low-cost public lands in Patagonia. In 1885, Moyano got permission to grant grazing lands to Malvinenses who wanted to settle in the continental area. This encouraged sheep producers of British such as Waldron brothers and Wood \& Tomas Greenshields, who occupied South and Center areas of Santa Cruz (Coronato 2018). Likewise, the concession of lands between important groups of Punta Arenas (Chilean town) delivered fiscal lands to Malvinense investors in northern Tierra del Fuego Island. Some beneficiaries were Juan Hamilton, Thomas Saunders, Hyle and Ness from Falkland, and settled local merchants such as José Nogueira (Portuguese origin) and José Menéndez (Spanish origin). For "activating the formation of a Patagonian land market" in the 1890s, Argentine Government began an intense campaign in Europe to sell land implementing express advertising strategies. A contract signed in 1888 between President Carlos Pellegrini and Adolfo Grünbein, who was a German lender and broker land living in Buenos Aires, gave authorization considering the special law (No. 3,053) approved in 1894 to sell lands. This law endorsed a direct sale for one million hectares in unbeatable conditions to buyers. The agents interested could opt for lands in Chubut or Santa Cruz, latter being the area where significant transfers took place. They distributed the lands transferred by Grünbein among 21 buyers, 14 of them corresponded to 
livestock companies installed already in different areas of Chile and Santa Cruz (Bandieri 2006 and 2018). ${ }^{3}$

These land concessions had an important impact on Santa Cruz and Tierra del Fuego. At the end of the 19th century Punta Arenas became the most dynamic point in southern Chile because of its strategic position. It was the only interoceanic communication between Puerto Montt and the Magellan region until before 1915, at the opening of the Canal of Panama. These structural conditions influencing the groups linked to economic dynamics of Strait of Magellan to transfer wool and frozen sheep meat for sale in European markets through Magellanic port. At the beginning of the 20th century, the participation of merchants from Punta Arenas expanded rapidly. Some of them become owners and / or tenants of new fiscal lands at Tierra del Fuego Island and Santa Cruz, Argentina. To speed up the settlements, President Roca installed a telegraph line between Cabo Vírgenes and Punta Arenas, while the Chilean government eliminated all customs taxes to transform Punta Arenas into an economic capital of a vast region that, over the international limits, extended from Payne to Cape Horn and from Chubut to Tierra del Fuego (Map 1). Also, at the end of the1910s, Strait of Magellan had its greatest commercial boom; $50 \%$ of the sheep sent to foreign markets came from Argentina (Martinic 1975, 305).

\footnotetext{
${ }^{3}$ Adolfo Grünbein, married with Sofia Seeber, was a land broker. He supported to the Augusto Link \& Co. started up in 1886, - German company dedicated to export and foreign trade-, the Bank of Antwerp, and the farmers Juan Hamilton and Tomas Saunders.
} 


\section{Journal of Evolutionary Studies in Business}

Map 1 Influence area of city-port of Punta Arenas (Century XIX and first decades of XX)

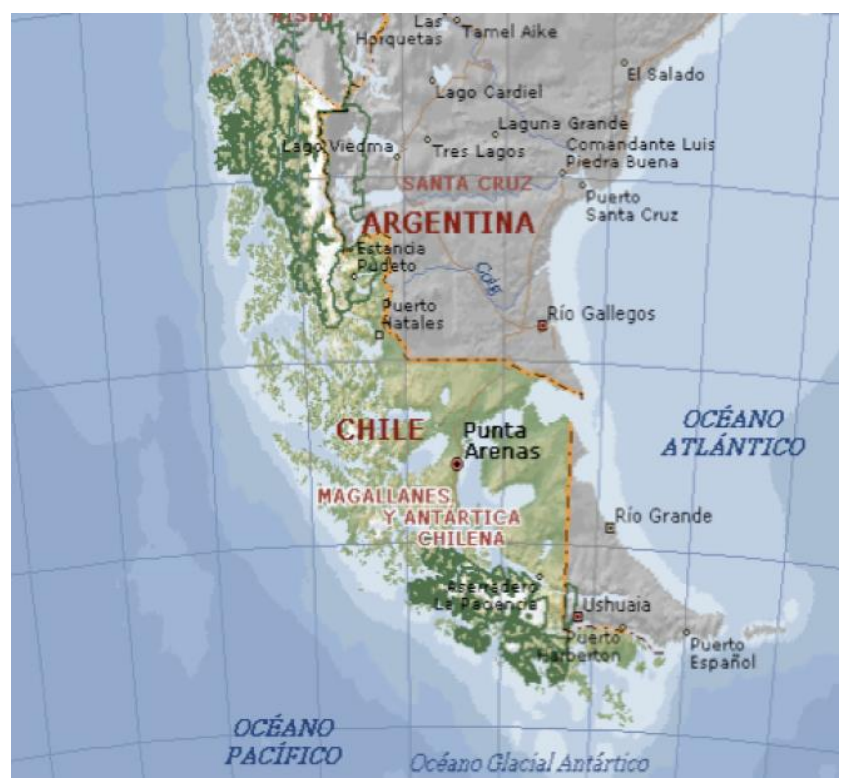

Source: http://www.estrecho-de-magallanes-punta-arenas/mapa.htm

One important fact is that the land concession stage favored the first foreign inhabitant groups in the Magellan region. But how do they established in previous decades and how they developed commercial abilities to establish agreements in outside markets in Europe? A general answer is that the relational capital accumulated by them carried out to establish political contacts in Chile and Argentina and to achieve incipient internationalization, which forcing to relativize the cited notion of autarchy.

Although some of the first commercial networks become weak in 1868, they permitted to seek markets outside the region and to organize the production. While foreign investments had effects not only in the nascent installed capacity, but in new associations for exploring and exploiting commercial routes abroad. Some individuals and families became success agents and their companies advancing throughout the 20th century overcoming to adverse local conditions as we'll see ahead. 


\section{Businessmen: 1868-1908}

From Punta Arenas to most Austral area of Argentine Patagonia, men like José Nogueira Rua, Elías and Mauricio Braun, and José María Menéndez arrived by the same period. In a short time, they become important merchandise and businessmen. But where did these characters come to the Magellan region? What elements defined the first commercial, social and personal alliances in Punta Arenas? Were their ventures a key piece in the emergence of new business associations to improve regional productive development? Only they responded temporally to foreign demand of products or directed their offers in foreign markets?

Since the 1860s most foreign settlers arrived at Punta Arenas from Spain, Switzerland, Portugal, France, Germany, Falklands and Great Britain. The multicultural landscape at the territory of Magellan (ethnicity bases) helped them to establish commercial networks and new political ties —after the concessions occur- with officials and legislators from Chile and Argentina, as Bandieri has pointed out (2015). Then, some agents promoted the expansion of their local businesses and a structure as a definition of their companies and speed-up connecting with capitalism abroad. The next three business genealogies offer some clues. The groups arrived between the decades of 1870 and 1930, their businesses had a family organization in the majority and among all of them they started up the family business network Braun-Menéndez Behety.

III.1 From Portugal to Punta Arenas: the "sea lion" captain

José Nogueira Rua (1845-1893) was born in Via Nova de Gaia, a small and humble rural town of Porto, Portugal. Without educational instruction and the age of 12 approximately, he embarked on a sailboat towards Havana (Martinic 2001c, 19). After passing through Rio de 
Janeiro, Montevideo, Buenos Aires and El Callao, he arrived at Punta Arenas at 21 years old (1866) to try his luck. He had no capital, no family, and only he had the knowledge gained during his marine vessel's trips (Lafuente 2015, 10). For Martinic. (2001c, 26-27), the first contact of José Nogueira to local activities in Punta Arenas enjoy hunting of sea lions "of two hairs". ${ }^{4} \mathrm{He}$ had knowledge of boats but learned to hunt because of his friendship with Luis Piedra Buena, an Argentine neighbor.

This rough activity projected to José Nogueira who rapidly upgrading his local economic position. Then Nogueira could extend its first commercial networks to foreign markets and buy his first ship "Anita", and integrate his fleet of vessels that later included to "San Pedro", "San José", "Ripplig Wave", "Martha Gale", "Rescue", "Express" and " Pichincha". The next step carried out simultaneously the development of hunting with the sale of products. It allowed the Portuguese to establish the José Nogueira \& Co. a warehouse that operated between 1869 and 1874. The firm included trade of "general stuff" and sale of naval items. The collaboration with one of the most important interoceanic companies in the region, called Compagnie Maritime du Pacific, helped Nogueira to join his firm shipping services. (Martinic 2001c, 59). This learning process will be decisive in his career. Combined these early activities with the rescue of shipwrecked loads called "raques". Later started timber trade, parking and, cabotage services. In 1876, almost a decade after arriving, specialization distinguished José Nogueira's career in maritime activities focused on sea hunting, commerce and specialized services. In this year his fleet had an important mission to sheep's transportation to Punta Arenas. When end border disagreements between Chile and Argentina in 1881, the economy of Punta Arenas intensified because of raising rates of population and a number of firms established. They domiciled some

\footnotetext{
${ }^{4}$ This activity started by Real Compañía Marítima founded in 1789 in Puerto Deseado, north of Punta Arenas in the Argentine (Barbería 1994).
} 
companies in Valparaíso — an important regional business hub — where many businessmen in Patagonia could take part as shareholders and earn profits to get new companies. It applies to say that route from Punta Arenas to Valparaíso opened the new ties with Europe. ${ }^{5}$

After offering his services to the first farmers, Nogueira considered another activity the getting of land concessions and an alternative route of commercial projects from sheep breeding. Its possibilities of expansion depended on sound investments (own resources) and the relational capital accumulated until that moment to successful political lobby. Thus, in 1881 he got directly the first of three land concessions on the north bank of Pescado River. As a visionary, Nogueira introduced administrative innovations to get money: the formalization of land transferences to next partners must be through a social firm to establish an effective mode to capitalization. We would define the role of his partners and the terms of the collaboration in the new society. For the first concession he started up the Nogueira \& Co., in partnership with Juan Hurtado. The following year (1882) he constituted the Tierra del Fuego Sheep Farm Co., to establish the Peckett Harbor a first high farm in getting have wiring. To install the Cabo Negro farm, José Nogueira invited as partner to Elías Braun and in partnership with him also supplied top meat through the Braun \& Nogueira Co. (Martinic 2001c). This association was the beginning of a long relationship between Nogueira and Braun's family members that resulted in marriage Jose Nogueira and Sara Braun.

By the 1880s, Nogueira was a successful businessman in the commercial, maritime and farm activities, and was the beginning in mining exploration. To merge his commercial networks, he avoided intermediaries and controlled directly internal and external distribution and supply

\footnotetext{
${ }^{5}$ This area, absolutely peripheral in the agro-export structure of Argentina and Chile, centered in the ports of Buenos Aires, in the first case, and of Valparaíso and Concepción (Martinic 1972; 1975 and 1976; Barbería 1991 and 1995).
} 
routes. In Chile, Nogueira had nine suppliers established in Valparaíso and two more in Concepción and Talcahuano (Martinic 2001c, 66-67). The Nogueiras' international networks included suppliers and buyers from UK, Uruguay, Germany, France and Portugal. To fulfill all commercial commitments, Nogueira turned to "attorneys" -legal representatives- take decisions allowed in his name ${ }^{6}$. Closely Nogueira's collaborators were Dr. Thomas Fenton an export agent and commercial promoter, Mauricio Braun who was his apprentice and later Nogueira's agent and partner, Walter Curtze, and Thomas Greenshields.

In 1885 José Nogueira associated to Ramírez and Fuhrmann to do mining activities, also to Ramírez, Braun and Mancilla. Unlike commerce and shipping firms, he only was as a capitalist partner. The mining concessions that Nogueira got "América" (transferred by Juan Manuel Frías), "Anita", "San Pedro" and "San José", while encouraged to his collaborator Mauricio Braun to getting the mining belongings "Sofía", "Sara" and "Ana". Although Mauricio not yet related to Nogueira as family, the relationship of trust between the two allowed him to expand his possessions and save transaction costs based on friendship.

In 1886, Nogueira showed his management and business capabilities when restructured his main business. He contacted the French specialist Gastón Blanchard, who had been a collaborator of the A. Trouillé Co. a company established in Valparaíso. Firstly, Nogueira dissolved the José Nogueira \& Co., to replace it with the Nogueira \& Blanchard Co., which registered 80 thousand pesos paid in equal parts by the partners in 1887 . Internal changes involved the creation of commercial, maritime and representation sections. The management was by Juan Blanchard, Mauricio Braun, and Walter Curtze respectively, while Gastón Blanchard was the general manager (Martinic 2001c, 113). It should be note that reorganization

\footnotetext{
${ }^{6}$ Rarely the literature on entrepreneurs has discussed about legal representatives in LATAM, despite of they are very important characters in business accompaniment, performance and business success.
} 
was blunt in Nogueira's businesses. By then the shipping activities were emerging as an important local and foreign business niche.

Nogueira's practices allow us to identify another two important agents: the concessions broker and the land broker. They were key for agricultural and livestock activities. The firsts conducted lobby to get land contracts, and the second were allies for the operation of farms. Once got the concessions, Nogueira formalized new companies, as anonymous, to transfer land and exploit them. For example, after the second concession got by Nogueira in 1889 in Tierra del Fuego (equivalent to 180 thousand hectares), he started up the Sheep Farm Company of Tierra del Fuego (Lafuente 2015, 78). In the same year Nogueira contacted to cattle-financial group Waldron \& Wood Co. represented by Mont E. Wales to reallocate titles and make up in 1890 The Land of Fire Farming Co. (based in London). ${ }^{7}$ In coordination with Nogueira, Mauricio Braun got another concession for 170 thousand hectares. Unfortunately, the partners not found immediately and Nogueira contacted again to group Waldron \& Wood Co. Two years later they accepted the terms of transference land and started up The Philip Bay Sheep Farming Co. in similar conditions as before company, being Braun the principal (Martinic 2001b and 2001c). These two operations of Nogueira confirm his assumption about a previously planned land petition, and the strong trust between he and Braun.

The greatest of Nogueira's successes presented in 1890 upon receiving the third concession for 1,009,000 hectares. This unluckily coincided with growing deterioration of Jose's health. In 1891, José worsened affecting both business and family relationships (Martinic 2001b, 88, 2001c, 138). In 1892 the scenario for Nogueira aggravated when unexpectedly Gastón Blanchard, his partner and friend, dead. A surprising decision came when José instructed his

\footnotetext{
${ }^{7}$ In the company Nogueira was one of five shareholders, contributing $£ 250,000$.
} 
attorneys and partners to start the liquidation of the Nogueira \& Blanchard Co., setting a term not exceeded six months from July of that year (Martinic 2001c, 139-141). Before the end of 1892, Nogueira caused surprise again when agreed the session of a third of grand concession to his friend and partner Ramón Serrano Montaner, who was the "concession broker". The one who was now part of Nogueira's family, Mauricio Braun, asked his brother-in-law to stop the liquidation. Without success in the negotiation, Braun had to advance in the company's liquidation but not to lose the company, proposed to Juan Blanchard buying the share holds to get the transfer of the company. The Braun alternative finally proceeded after Nogueira's death, who was his mentor, partner and friend.

Tenacity and perseverance that became a commercial and an economic legacy must distinguish Nogueira. In his best moments Nogueira, instances from Chile and Brazil as a distinguished citizen. His productive achievements and projection of local development were indisputable (Martinic 2001c). One of Nogueira's social relations impacting in business durability was her marriage to Sara Braun, Mauricio's sister. Besides allowed increasing his relational capital in the political sphere at the highest levels. Braun's family was respectable and known in a political environment.

The celebration of the Nogueira and Braun marriage was in 1887 and finished in 1892 . Nogueira's marriage had no descendants. His widow and brother-in-law. as a petition of Sara, reproduced the capital, business companies, and land. In consequence, Sara Braun became in the greatest heiress. This projected the second generation of Braun's family, including to José Menéndez, who was the Nogueira's business rival in Punta Arenas (Table 1). 
Table 1. The business genealogy of José Nogueira

\begin{tabular}{|c|c|c|c|c|}
\hline Period & $\begin{array}{l}\text { Productive } \\
\text { activities } \\
\text { founder }\end{array}$ & Type of networks building & $\begin{array}{l}\text { Type of } \\
\text { capital } \\
\text { accumulated }\end{array}$ & Skills \\
\hline 1866 & - & $\begin{array}{l}\text { Social: No family and } \\
\text { friendship links when he } \\
\text { arrived at Punta Arenas (age } \\
\text { 21) } \\
\text { Business: -- }\end{array}$ & - & Marine \\
\hline $\begin{array}{l}1867- \\
1876\end{array}$ & $\begin{array}{l}\text { - Commercial } \\
\text { and early } \\
\text { international } \\
\text { projection } \\
\text { - Hunting sealion } \\
-\quad \text { Trade of } \\
\text { feathers and wild } \\
\text { skins } \\
\text { - Raque }\end{array}$ & $\begin{array}{l}\text { Social: Local Friendship } \\
\text { Property: landowner } \\
\text { Commercial: Local buyer } \\
\text { (indigenous) and abroad } \\
\text { buyer, local and abroad seller } \\
\text { Business: Owner }\end{array}$ & $\begin{array}{l}\text { Financial } \\
\text { Relational } \\
\text { (friendship) } \\
\text { Commercial }\end{array}$ & $\begin{array}{l}\text { Marine } \\
\text { Deal maker } \\
\text { Visionary }\end{array}$ \\
\hline $\begin{array}{l}1876- \\
1882\end{array}$ & $\begin{array}{l}\text { - Shipping by sea } \\
\text { - Local livestock } \\
\text { from } 1876 \text { to } \\
1882 \text { through } \\
\text { innovative } \\
\text { management } \\
\text { methods Foreign } \\
\text { - commerce }\end{array}$ & $\begin{array}{l}\text { Social: } \text { Trust personal } \\
\text { Land: land applicant and } \\
\text { landowner } \\
\text { Commercial: local and } \\
\text { abroad seller } \\
\text { Service provider: local and } \\
\text { abroad maritime shipping } \\
\text { Employer: local and foreign } \\
\text { specialized workers } \\
\text { Business: Owner }\end{array}$ & $\begin{array}{l}\text { Financial } \\
\text { Relational } \\
\text { Commercial } \\
\text { Political }\end{array}$ & $\begin{array}{l}\text { Deal Maker } \\
\text { Visionary } \\
\text { Applicant of } \\
\text { Land } \\
\text { Concessions } \\
\text { Shareholder } \\
\text { Businessman }\end{array}$ \\
\hline $\begin{array}{l}1886- \\
1890\end{array}$ & $\begin{array}{l}\text { - Specialization } \\
\text { of own business } \\
\text { with an internal } \\
\text { reengineering } \\
\text { and new } \\
\text { partnerships } \\
\text { - Exploring in } \\
\text { mining getting } \\
\text { concessions }\end{array}$ & $\begin{array}{l}\text { Social: Trust personal, } 2^{\text {nd }} \\
\text { marriage and family } \\
\text { Land: land applicant, } \\
\text { landowner, land grabber } \\
\text { Service provider: local and } \\
\text { abroad commercial, maritime } \\
\text { shipping, representing } \\
\text { Farm: sheep breeder, } \\
\text { employer of foreign } \\
\text { specialized workers } \\
\text { Business: Owner, partner in } \\
\text { formal societies (foreign and } \\
\text { local), land brokers' informal } \\
\text { partner, land intermediaries' } \\
\text { formal partner, mining } \\
\text { intermediaries' formal share, } \\
\text { friendship partner }\end{array}$ & $\begin{array}{l}\text { Financial } \\
\text { Commercial } \\
\text { Relational } \\
\text { (friendship, } \\
\text { parental and } \\
\text { political) }\end{array}$ & $\begin{array}{l}\text { Applicant of } \\
\text { Land } \\
\text { Concessions } \\
\text { Innovative } \\
\text { visionary } \\
\text { Shareholder } \\
\text { Businessman }\end{array}$ \\
\hline
\end{tabular}




\begin{tabular}{|c|c|c|c|c|}
\hline Period & $\begin{array}{l}\text { Productive } \\
\text { activities } \\
\text { founder }\end{array}$ & Type of networks building & $\begin{array}{l}\text { Type of } \\
\text { capital } \\
\text { accumulated }\end{array}$ & Skills \\
\hline $\begin{array}{l}1890- \\
1892\end{array}$ & $\begin{array}{l}\text { - Searching new } \\
\text { profits by land } \\
\text { concessions }\end{array}$ & $\begin{array}{l}\text { Social: Trust personal and } \\
\text { family } \\
\text { Land: land applicant, } \\
\text { landowner, land grabber } \\
\text { Service provider: local and } \\
\text { abroad commercial, maritime } \\
\text { shipping, representing } \\
\text { Farm: sheep breeder, } \\
\text { employer of foreign } \\
\text { specialized workers } \\
\text { Business: Owner, partner of } \\
\text { formal societies (foreign and } \\
\text { local), land brokers' informal } \\
\text { partner, land intermediaries' } \\
\text { formal partner, mining } \\
\text { intermediaries' formal share, } \\
\text { friendship and family partner }\end{array}$ & $\begin{array}{l}\text { Financial } \\
\text { Commercial } \\
\text { Relational } \\
\text { (friendship, } \\
\text { parental and } \\
\text { political) }\end{array}$ & $\begin{array}{l}\text { Applicant of } \\
\text { Land } \\
\text { Concessions } \\
\text { Shareholder } \\
\text { Businessman }\end{array}$ \\
\hline
\end{tabular}

Source: Authors' elaboration.

Synthesizing, the last name Nogueira did not continue, although the companies formed by José survived because of the intervention of his widow Sara and Mauricio Braun. Mauricio was a member of the heiress's nuclear family, and also his position was important because he had worked in the Nogueira business network. This succession was successful because the family structure continued by the successor family, who was the main administrator of a network of merged companies. The corporate governance changed in the minimum, and totally in the property. A branch that allowed continuity followed the second generation of these two families. Nogueira's brother-in-law followed his legacy in business, endured the main firm and advanced in his business career, taking advantage of the social network in which, he already took part. 


\section{III.2 The Braun Hamburger family}

After settling in Telsen, a town in the Russian Empire — today Republic of Latvia — Elías Braun and Sofia Hamburger emigrated to Hamburg, then to London and finally to South America. In 1872, the family of five members arrived at Buenos Aires, ${ }^{8}$ where a Chilean diplomat offered to Elías Braun basic goods to settle in the south`s country. Like other families, families' Braun received 24 hectares and 12 additional for each child over 14 years old. The context for the settlement in southern Chile will be the first institutional resource used by the head of the Braun family, as Nogueira did. Individuals and groups take advantage of the institutional environment. Meanwhile, the institutional effects revealed in social continuity and the organizational in business. Because of this, as implied in the first section of this article, business families and family businesses are units that led to analyze institutions - in the long term - and sociobusiness behavior.

In 1874 Elías arrived at Punta Arenas, where had access to housing materials, one cow, one mare and food for the first six months (Lafuente 2015, 128). Originally Braun dedicated to sale leather, wool and ostrich feathers. These activities permit us to infer his first contact with José Nogueira. Historical references show that Elías Braun installed a small hotel - the Kosmosand also worked to extract coal. They strengthened their relationship when Elías started a business to merchandise imports from Europe through the Braun and Co. and receiving financial support from Nogueira. Later in 1881, both started up the Braun \& Nogueira Co. to supply meat (Martinic 2001b). As previously mentioned, in 1889 José Nogueira and Elías Braun ventured into livestock sharing land. The settlements built a small context for business

\footnotetext{
${ }^{8}$ The children Sara, Mauricio and Oscar were born in Telsen, and Ana was born in Paraguay. The three minors, Fanny, Mayer and Juan were born in Punta Arenas (Lafuente 2015, 18).
} 
in Punta Arenas, which was conducive to consolidate an internal network of owners and businessmen.

Mauricio Braun Hamburger, the second son of his family, was a provisional employee used as a child in the Bloom, Schröeder \& Co. and later in the José Menéndez's stores. In 1880 (15 years old), he became a formal employee at the Nogueira's company. Without knowing it, Braun would become Nogueira's trusted staff. He worked as a sales agent, in representation of Nogueira's company and partner in the Nogueira \& Blanchard Co. Nogueira was also his teacher, friend and later brother-in-law. Being yet young, Braun started his own business, although with Nogueira's approval. In 1885, his boss encouraged Mauricio to apply for concessions of land and mines, placing them next to those of Nogueira. In 1888, Mauricio established the Scott \& Braun Co. to manage the La Fortuna sawmill and two others: Río Seco and Tres Brazos. In 1889, taking advantage of Nogueira's relational capital, Mauricio got 170,000 hectares to be exploited in Santa Cruz and San Julian areas. In 1890, Mauricio established the Braun \& Guillaume Co. and two years later he joined to the Cameron Campbell Co. in partnership with James Campbell, and John Cameron (Scottish) hired as a sheep specialist by Nogueira's farms. In the same period, without apparent Nogueira's vigilance, Braun got the representation of New York Life Insurance at Punta Arenas.

The greatest business opportunity for Mauricio came in 1893 with his sister Sara Braun widowed of José Nogueira. She became the wealthiest and youngest businesswoman in the region. To follow the succession of inherited assets and capitals, Mauricio legally represented Sara as she wanted. The Peckett Harbor farm was the most profitable of Nogueira's commercial primaries. Mauricio managed it between 1893 and 1897 as requested by Sara. From 1898 onwards, Oscar Braun administrated this farm. The family is an institution that collaborates 
with the endurance of companies. In addition, nuclear families strengthen control, as did the second generation's Braun.

With the death of his brother-in-law, Mauricio concluded the transfer of the Nogueira \& Blanchard Co., agreed with Juan Blanchard. Once proportions corresponding to Nogueira and Blanchard widows were paid. The old firm changed its name to Braun \& Blanchard Co. to restart activities that were still in force (Martinic 2001a, 152-153 and 2001b, 98). If José dissolved the José Nogueira \& Co. to restructure it implementing the commercial and shipping sections and later to started up the Nogueira \& Blanchard Co. - in collaboration to Juan-, then the third firm Braun \& Blanchard Co. —reorganized by the successor Mauricio Braunrepresents the perdurability of the two early business. The changing of this company is a succession of names and associates where Braun is the last and also the successor of Nogueira by kinship. This organizational example confirms that durability of a company does not require the same corporate name, the importance is how shareholders control the company; it sustained the survival process when the roots maintained but adapting to new circumstances. Some trajectories also are perdurable by external buyers.

Here the business perdurability associates to continue the Braun's family sustained it by marriages of the second generation. Business trajectories depended on the management capabilities of Sara and Mauricio Braun. Also, decisions taken by them around the large concession of one million hectares were crucial to family continuity. The interdependence between the social and the commercial is so strong in the family businesses of the secondgeneration Braun and depended on the nuclear members.

With a few months Braun's brothers rushed the constitution of new company to make effective the commitments gained by José Nogueira. In 1893 was organized the "Operating Society of 
Tierra del Fuego" (onwards SETF — acronym in Spanish-). The capital was one million pesos divided in 2,000 shares. Sara Braun gained 350 shares; Mauricio Braun on his own and representing to Juan Blanchard, and Elias and Oscar Braun acquired 425; José Menéndez gained 200; Guillermo Wilms 100; Cruz Daniel Ramírez 100; Gustavo A. Oehninger 100; and Ramón Serrano Montaner 100 shares. $^{9}$ In the negotiation with the British Duncan Fox Co., Peter H. Mc Clelland was the President and Mauricio Braun manager-director.

The SETF became one of the most relevant companies in the Austral region for decades. In this business Braun developed corporate transformations and perfected the rural management capabilities introducing the figure of "farm stay administrator", which was considered by Martinic $(2001 b, 107)$ as a new "executive labor institution in rural stewardship". The company came to own 1,700,000 hectares and 12 million sheep in the fields on both sides of the Magellan Strait and international Chile and Argentina border, generating multiplier effects on the businesses of Braun's family and promoting an integrated diversification process during the following decades.

The SETF became a mother-company in Braun's family and joined another local family. In 1895 Mauricio married Josefina Menéndez-Behety, José Menéndez’s daughter. The marriage has 10 children. Carlos, Alejandro and Oscar Braun Menéndez-Behety took part in family businesses, contributing to the configuration of a strong business family. In 1896 Braun was pointed as Consul of the U.S. in the Magellan area; the same year Stubenrauch \& Braun Loading Dock Society could not reinforce shipping services converting the local dock in a multiservice platform. During this period the Braun \& Blanchard Co. already had a fleet of 6 ships. ${ }^{10}$

\footnotetext{
${ }^{9}$ As a result of the agreement between Braun's brothers and Ramón Serrano Montaner who was Nogueira's friend and broker land and owner of third part of great concession.

${ }^{10}$ Fifteen years later, the maritime section of this company, offered too passenger cabotage, freight transport, as well as ship rescue services eliminating the old "raque" carried out by private boats since 1860s at Magellan Strait.
} 
The commercial section expanded to ports Río Gallegos (1896), Santa Cruz (1899) and San Julian (1900), all in National Territory at this moment, then Santa Cruz province.

Braun had shareholders outside family businesses which included Electric Light Company Punta Arenas (since 1897) and Bank of Punta Arenas (since 1900). In banking, Braun took part in the opening process and later as a shareholder and also served as Vice president in the first board. During next periods 1903-1909 and 1913-1932, he was the bank President. Braun also managed the Braun \& Blanchard Co. which absorbed the Bonacich Hnos. \& Co. in 1899 to control activities of assembly and reparation to his fleet of ships (Martinic 2001b and 2001c). Between 1903 and 1904, Braun managed the transfer of new lands to attract settlers and boost livestock farming in association through the Aysen Industrial Society and the Baker-Mauricio

\section{Braun Operating Co.}

The transition to the 20th century meant to Mauricio Braun the incursion into new activities. The opportunities go beyond the search for land the federal government encouraged that at the end of the 19th century at Tierra del Fuego area. Since 1905 Braun visualize in the refrigeration industry a niche of opportunities. This year he formed The South American Export Syndicate associated to English backing through the Houlder Brothers \& Co., Bermúdez \& Co., and other British partners (Martinic 2001a, 199-200). Braun also ventured into whaling in partnership whit owner of the Bruyne, Andersen \& Co., ${ }^{11}$ and since 1906 through the own firm the Magellan Whaling Co., in which Alejandro Menéndez Behety and José Menéndez (brother-inlaw and father-in-law), among others, also took part as shareholders. The building sector,

\footnotetext{
${ }^{11}$ Following Nogueira's footsteps, society was made possible by the inclusion of Adolfo Andresen who was the expert in the "whaling" activity and knew how to handle modern technology.
} 
Mauricio created at the same year the Braun \& Foretich Co. associating with Natalio Foretich, who was a Croatian building specialist.

The expansion of the second-generation businesses to which Mauricio Braun belonged advanced in the number of businesses. For this he used the extended family, but especially third parties. This was so because Braun's children in 1910 decade were not of age to be part of the business. Braun's trajectory shows how the management of social relations accompanied the management of new businesses and the management of a local network of suppliers.

When Braun completed land transferences and concluded the inclusion of The Philip Bay Sheep Farming Co., into SETF (1906), he finishes his participation in this company. Then Braun started a new stage in business as a land grantee in Argentina. His sister Sara continued doing business associated to farm activities in Chile and later in Argentina. She formed the Livestock and Commercial Corporation "Sara Braun". Shareholder structure in its company was a nuclear family business type to control the business. While Mauricio Braun in less than one decade became an important landowner and industrial. Was lessee of 461,288 hectares, and leaser of 175 thousand hectares using the name of third parties in Argentina. The Tordillo Rocks Co. (San Julian Union) applies to get concessions in the San Julian area in 1907. In partnership with Alejandro and José Menéndez Behety, Braun, also gained in 1908 the stock package of Pastoril Society Glencross and bought the farms El Librún and La Carlota. While the Santa Cruz Trade Union Society managed the creation of The Southern Patagonia Sheep Farming Co. (Martinic 2001b).

By 1908 Mauricio Braun's business career has already merged, but the best was yet to come for him and the Braun and Menéndez Behety families. The same year Mauricio agreed with José Menéndez the merger of a commercial branch, applying a social capital for 1.5 million 
Argentine pesos. The companies of the Braun and Menéndez Behety until 1908 did not expand

to Argentina because the place of residence of the two the families was Punta Arenas.

This was a family strategy for expanding outside Chile. As a result of this agreement they created the Import and Export Corporation of Patagonia Anonymous Society operating with a council in Buenos Aires and attended at Punta Arenas. This is the moment of birth of $L a$ Anónima. José Menéndez was the first President of new company and as Vice president Mauricio Braun, while Juan Blanchard was director in the first place, and Pablo Dietert and Alejandro Menéndez Behety alternated as directors, and Esteban Ferrari as general manager (Martinic 2001b).

Table 2. First stage of business genealogy of Mauricio Braun 1874-1910.

\begin{tabular}{|c|c|c|c|c|}
\hline Period & $\begin{array}{l}\text { Productive } \\
\text { activities as } \\
\text { founder }\end{array}$ & $\begin{array}{l}\text { Type of networks } \\
\text { building }\end{array}$ & $\begin{array}{l}\text { Type of } \\
\text { capital } \\
\text { accumulated }\end{array}$ & Skills \\
\hline $1874-1880$ & - & $\begin{array}{l}\text { Social: Family. He } \\
\text { arrived in Punta Arenas } \\
\text { being a child (age 9) } \\
\text { Business: -- }\end{array}$ & $\begin{array}{l}\text { Relational } \\
\text { (parental) }\end{array}$ & - \\
\hline $1880-1888$ & \begin{tabular}{lr}
- & \multicolumn{2}{r}{ Sawmills } \\
Manager & in \\
supervision & of \\
José Nogueira & \\
- Insurance &
\end{tabular} & $\begin{array}{l}\text { Social: Family and Trust } \\
\text { personal } \\
\text { Land: landowner } \\
\text { Business: apprentice, } \\
\text { owner in first company, } \\
\text { partner in formal } \\
\text { societies, land brokers' } \\
\text { informal partner, land } \\
\text { intermediaries' formal } \\
\text { partner, representing, } \\
\text { friendship partner }\end{array}$ & $\begin{array}{l}\text { Relational } \\
\text { (parental) }\end{array}$ & $\begin{array}{l}\text { Apprentice } \\
\text { Business } \\
\text { assistant } \\
\text { Applicant of } \\
\text { Land } \\
\text { Businessman }\end{array}$ \\
\hline 1888-1892 & - Livestock sector & $\begin{array}{l}\text { Social: Family and Trust } \\
\text { personal } \\
\text { Business: owner, partner } \\
\text { in formal societies, land } \\
\text { intermediaries' formal } \\
\text { partner, friendship } \\
\text { partner }\end{array}$ & $\begin{array}{l}\text { Relational } \\
\text { (parental) and } \\
\text { Commercial }\end{array}$ & $\begin{array}{l}\text { Applicant of } \\
\text { Land } \\
\text { Concessions } \\
\text { Businessman }\end{array}$ \\
\hline
\end{tabular}




\begin{tabular}{|c|c|c|c|c|}
\hline Period & $\begin{array}{l}\text { Productive } \\
\text { activities } \\
\text { founder }\end{array}$ & $\begin{array}{l}\text { Type of networks } \\
\text { building }\end{array}$ & $\begin{array}{l}\text { Type of } \\
\text { capital } \\
\text { accumulated }\end{array}$ & Skills \\
\hline 1893-1906 & $\begin{array}{l}\text { - Testamentary } \\
\text { succession officer } \\
\text { - Shipping and } \\
\text { commercial } \\
\text { - Livestock sector } \\
\text { - Refrigeration } \\
\text { industry } \\
\text { - Bank and light } \\
\text { services }\end{array}$ & $\begin{array}{l}\text { Social: Family, trust } \\
\text { personal, marriage } \\
\text { Land: landowner, land } \\
\text { grabber } \\
\text { Service provider: local } \\
\text { and abroad commercial } \\
\text { and maritime, bank, light } \\
\text { Manufacture: family } \\
\text { business, partner in } \\
\text { formal societies (local } \\
\text { and foreign), former, partner } \\
\text { Business: owner, land } \\
\text { in formal societies, formal } \\
\text { intermediaries' } \\
\text { partner, friendship } \\
\text { partner mining } \\
\text { intermediaries, member } \\
\text { of board farm: sheep breeder, } \\
\text { Farm } \\
\text { employer of foreign } \\
\text { specialized workers }\end{array}$ & $\begin{array}{l}\text { Relational } \\
\text { (parental), } \\
\text { Financial, } \\
\text { Commercial, } \\
\text { and } \\
\text { Political }\end{array}$ & $\begin{array}{l}\text { Applicant of } \\
\text { Land } \\
\text { Shareholder } \\
\text { Businessman }\end{array}$ \\
\hline $\begin{array}{l}1906-1910 \\
\text { (with } \\
\text { address at } \\
\text { Chile and } \\
\text { Argentina) }\end{array}$ & $\begin{array}{l}\text { - Commercial } \\
\text { - Whale's hunt } \\
\text { - Livestock sector }\end{array}$ & $\begin{array}{l}\text { Social: Family and Trust } \\
\text { personal } \\
\text { Land: Landowner, land } \\
\text { grabber } \\
\text { Service provider: local } \\
\text { and abroad commercial } \\
\text { and maritime, bank, light } \\
\text { Manufacture: } \\
\text { refrigerator industry } \\
\text { Business: owner, partner } \\
\text { in formal societies, land } \\
\text { intermediaries' formal } \\
\text { partner, friendship } \\
\text { partner, merge business }\end{array}$ & $\begin{array}{l}\text { Relational } \\
\text { (parental) } \\
\text { Commercial } \\
\text { Political } \\
\text { Union }\end{array}$ & $\begin{array}{l}\text { Applicant of } \\
\text { Land } \\
\text { Shareholder } \\
\text { Businessman }\end{array}$ \\
\hline
\end{tabular}

Source: Authors' elaboration.

Braun had taken part as a founding partner and / or partner in 48 companies (31 in Chile and 16 in Argentina) with two mother-companies: the SETF and La Anónima. The Braun's associations continued in alliance with suppliers through the formal partnership. For example, 
in 1910 Braun had an association with the founder of "Minerva" Workshop Maestranza - active since 1897- to take the control in reparation of machinery and not to depend of external services. The reconstruction of Braun's business genealogy permits to identify the important milestones in the business career of Mauricio and the networks operating between 1874 and 1910 (Table 2). The durability of family businesses depended on Mauricio Braun's associations with his sister Sara and his partner José Blanchard. La Anónima, which functioned as a merge commercial company, positioned a new era of business and the continuity of the BraunMenéndez Behety lineage since 1908. The same table shows that companies merged and acquired by Braun were formal suppliers, but they did not operate as a family association.

\section{III.3 Asturians in Punta Arenas}

José María Menéndez Menéndez (1846-1918) was born in Santo Domingo de Miranda in Asturias, Spain; from there embarked towards Havana at 14. Historians show that in 1866 he got a position as "bookkeeper" (accountant) in Buenos Aires in a naval hardware store called Corti Riva \& Co. and also in the German company Etchart \& Co. In 1875 he traveled to Punta Arenas representing to last one for recovering a debt from José Piedra Buena, who owned a commercial office dedicated to different branches (Lafuente 2015, 12-15; Martinic 1971, 1920). This event was crucial in the business life of this Spanish visionary, as we can see later. The references consulted show that Menéndez paid the Pedro debt to be in charge of his commercial store, which he would register as José Menéndez \& Co. ${ }^{12}$ José (33 years old) got married to María Behety Chapital, who was a daughter of Félix Behety and María Chapital, a Basque-French origin family.

\footnotetext{
${ }^{12}$ Piedra Buena was the master of José Nogueira in the hunting of sea lions. It can be explained the rivalry between Nogueira and José Menéndez.
} 
Since 1878 José Menéndez and family arrived at Punta Arenas, Chile. His first activities were the hunting sea lions and rescue of ships "raque" like few others in the town. Menendez also offered maritime services and traded feathers and wild skins, making agreements with indigenous people. Between 1880 and 1881 Menéndez borrowed a sawmill named "Union" for two years. Associated with Federico Arnald and José Montes, ${ }^{13}$ José also managed the Hotel del Puerto. Between 1882-1885, enabled the ranch of San Gregorio (Lafuente 1996). Through this farm, he developed a successful livestock system that gave him local economic and social prestige. Because of his local achievements, in 1892 Menéndez was appointed Vice Consul of Punta Arenas (Martinic 2001b, 72). Later José started up another farm associated to Francisco Bilbao through the Bilbao \& Co. This farm at Tierra del Fuego called Primera Argentina (1894) and had 80 thousand hectares. The institutional context of Land Concessions encouraged to commercial agents to take new risks and seek shareholders in the locality and Europe.

In 1897 Menéndez also took part in the constitution of the Electric Light Company of Punta Arenas being partner of Mauricio Braun, Juan Blanchard and Walter Curtze, among others. In this company he was the first board's President. Two years later, José gained 100,000 hectares in concession to the name of his sons Alejandro and José, which allowed him to start the Second Argentina (later María Behety Farm Stay); José took advantage of concession legislation and international market context and turned it far in one of most modern in Fuegian area. To be more efficient, José Menéndez introduced advance machinery as modern shears for shearing sheep (Martinic 2001b, 116-118). In 1907, almost in parallel to Mauricio Braun, José introduced to Punta Arenas the refrigeration industry through the Refrigerating Company of

\footnotetext{
${ }^{13}$ José Montes was the daughter's father-in-law.
} 
Patagonia. And in 1908, as it mentioned, achieved the merger of his commercial branch with Mauricio Braun.

A relevant fact to José's family and himself was the death of his wife María Behety in 1910. According to available biographical information, Maria's forced José to divide properties and actives among members of his nuclear family and to make up a new society organized as a nuclear family business. This succession can see as a strategic transfer of property rights because of the constitution of Livestock and Commercial Corporation Menéndez Behety and likewise considered an indicative of continuity of family bases and the nascent of a family office. For this reason, the typology of family a business is important. The new nuclear family business was the basis of continuity. In this family group the mother - María Behety — was a capital contributor and therefore could inherit, although she has not been a founding partner in business. In her perspective, only the nuclear shareholder can save the family. Table 3 shows José Menéndez business and a different style from José Nogueira and his son-in-law Mauricio Braun.

Table 3. The business genealogy of José Menéndez 1875-1910.

\begin{tabular}{|c|c|c|c|c|}
\hline Period & $\begin{array}{l}\text { Productive } \\
\text { activities as } \\
\text { founder and in } \\
\text { collaboration }\end{array}$ & $\begin{array}{l}\text { Type of networks } \\
\text { building }\end{array}$ & $\begin{array}{l}\text { Type of } \\
\text { capital } \\
\text { accumulated }\end{array}$ & Skills \\
\hline 1875 & $\begin{array}{l}\text { - Employed to } \\
\text { recover a debt }\end{array}$ & $\begin{array}{l}\text { Social and Business: -- } \\
\text { He arrived temporally to } \\
\text { Punta Arenas (age 29) }\end{array}$ & Commercial & Accounting \\
\hline $\begin{array}{l}1878- \\
1881\end{array}$ & $\begin{array}{l}\text { - Hunting of sea } \\
\text { lion } \\
\text { - Trade of feathers } \\
\text { and wild skins } \\
\text { - Raque } \\
\text { - Sawmills (C) } \\
\text { - Lodgings (C) }\end{array}$ & $\begin{array}{l}\text { Social: Trust personal and } \\
\text { family } \\
\text { Business: apprentice, } \\
\text { owner in first company, } \\
\text { partner in formal societies, } \\
\text { land brokers' informal } \\
\text { partner, } \\
\text { intermediaries'r formal }\end{array}$ & $\begin{array}{l}\text { Relational } \\
\text { (parental), } \\
\text { Commercial, } \\
\text { Financial and } \\
\text { Political }\end{array}$ & $\begin{array}{l}\text { Partner } \\
\text { Businessman }\end{array}$ \\
\hline
\end{tabular}




\begin{tabular}{|c|c|c|c|c|}
\hline Period & $\begin{array}{l}\text { Productive } \\
\text { activities as } \\
\text { founder and in } \\
\text { collaboration }\end{array}$ & $\begin{array}{l}\text { Type of networks } \\
\text { building }\end{array}$ & $\begin{array}{l}\text { Type of } \\
\text { capital } \\
\text { accumulated }\end{array}$ & Skills \\
\hline & & $\begin{array}{l}\text { partner, representing, } \\
\text { friendship partner }\end{array}$ & & \\
\hline $\begin{array}{l}1882- \\
1908\end{array}$ & $\begin{array}{l}\text { - Livestock sector } \\
\text { - Refrigeration } \\
\text { Industry } \\
\text { - Bank and light } \\
\text { services }\end{array}$ & $\begin{array}{l}\text { Social: Family and Trust } \\
\text { personal } \\
\text { Land: landowner } \\
\text { Service provider: local } \\
\text { and abroad commercial } \\
\text { and maritime, bank, light } \\
\text { Manufacture: family } \\
\text { business } \\
\text { Business: partner in } \\
\text { formal societies, land } \\
\text { intermediaries' formal } \\
\text { partner, friendship partner } \\
\text { Farm: sheep breeder, } \\
\text { employer of foreign } \\
\text { specialized workers }\end{array}$ & $\begin{array}{l}\text { Relational } \\
\text { (parental) } \\
\text { Commercial } \\
\text { Financial } \\
\text { Political }\end{array}$ & $\begin{array}{l}\text { Partner } \\
\text { Applicant of } \\
\text { land } \\
\text { Businessman }\end{array}$ \\
\hline $\begin{array}{l}1908- \\
1910\end{array}$ & $\begin{array}{l}\text { - Commercial } \\
\text { - Whale's hunt } \\
\text { - Livestock sector }\end{array}$ & $\begin{array}{l}\text { Social: Family and Trust } \\
\text { personal } \\
\text { Land: Landowner, land } \\
\text { grabber } \\
\text { Manufacture: family } \\
\text { partner in formal societies } \\
\text { Business: owner, partner } \\
\text { in formal societies, land } \\
\text { intermediaries' formal } \\
\text { partner, family business, } \\
\text { merge business } \\
\text { Farm: sheep breeder, } \\
\text { employer of foreign } \\
\text { specialized workers }\end{array}$ & $\begin{array}{l}\begin{array}{l}\text { Relational } \\
\text { (parental) }\end{array} \\
\text { Commercial } \\
\text { Financial } \\
\text { Political }\end{array}$ & $\begin{array}{l}\text { Partner } \\
\text { Applicant of } \\
\text { land } \\
\text { Businessman } \\
\text { Shareholder }\end{array}$ \\
\hline
\end{tabular}

Source: Authors' elaboration.

Jose Menéndez trajectory was so compact in terms of formal collaboration networks. Family and friendship linkages appeared as part of the majority of his companies. The heritage of a wife's family it was crucial in that regard to last part of his business life. To finish the period 1908-1910 Menéndez only took part in 10 companies, being the most important the Anonymous Society Importing and Exploiting Corporation of Patagonia known as La Anónima (a merger 
of the José Menéndez \& Co. and Braun \& Blanchard Co.). The last Menéndez mercantile participation was in 1916, two years before his death. This businessman adds in total 16 participations as a founder, in which nine also do Mauricio Braun.

\section{Two family groups and one business family: 1908-1935}

In Punta Arenas, the first group of settlers established since the second half of the 19th century until 1900 supported the first business activities and promoted slowly the family association. If Punta Arenas gained importance in trade and exports not all initial businesses enduring the next decades. Established groups initially experienced informal and limited partnership small businesses and then emerging gradually collective societies between two or more partners according to local and markets. When the range of action was broadened and more partners were included, it was that new types of firms emerged, with different structures, including family-type ones. In decades 1901 and 1920 had transformations suffered by businessman rooted in this region allowed some of them to remain active. Despite the geographical distance, the transport conditions and the peripheral condition in the commercial routes and political sphere, some settlers accumulated capital and developed bases to continue as family businesses. Unlike other contexts in LATAM that experienced arrival of foreign groups for settlement with participation of "land brokers", Punta Arenas evidenced the valuable of foreign ties and foreign families. Their members build commercial agreements with abroad to strengthen trade routes and achieve the expansion of economy in the southern Patagonian region; first in Chile, and then in Argentina. The differences in the composition of business groups and local trajectories show multiple ways to control value chains of production and distribution in Europe to accumulate capital. The three business genealogies reconstructed in this article related to control of the internal market and the foreign trade expansion process. Among the initial 
businessmen at Punta Arenas were Henry Reynard, José Nogueira, Rodolfo Stubenrauch, Guillermo Bloom, L. L. Jacobs and Juan Hurtado, and as the Blanchard brothers, Mauricio Braun, José Menéndez and José Montes and their families, among others.

IV.1 Towards the second generation of businesses family

Businesses at Punta Arenas, Chile experienced the first stage of growth between 1868 and 1881 based on commercial business to export hunting products, leather, and the increase the exotic feather traffic. With the offer of land concessions at the end of the 19th century, the rise of livestock began another phase of the local dynamic. By 1892 the companies of José Nogueira and José Menéndez represented 36.1\% of total commercial traffic (Martinic 2001b, 90). For period 1913-1918 Punta Arenas had:

“[...] Four commercial banks, 200 industrial and artisan establishments, over 400 commercial offices and many others [business] dedicated to the hotel industry; 300 cattle ranches ... and countless minor agricultural properties, and dozens of livestock companies, shipping, fishing, mining and oil businesses, communication by telephone, electricity and insurance, representing large capitals and investments [...]" (Martinic 2002, 84).

Some changes in assignation land legislation between 1903 and 1905, encouraged an incipient union of ranch owners through the "Committee for Defense of the Interests of the Pioneer Farmers". Two years later, the owners of farms started up the Society of Estancieros Unidos de Última Esperanza (1905), with participation of José Menéndez, Stubenrauch and Mauricio Braun (Martinic 2001b).

According to revised documents, the collaboration between Mauricio Braun and José Menéndez started in 1906 in the Whale of Magellan Co. Two years later produced the merger of their commercial companies to operate in Argentina through the La Anónima, giving rise in 
1908 a new family business of an extended type with two nuclear family business. Next generations will start up anonymous societies and take a further step towards the configuration of a strong business family. The new century will be a new époque to Braun business family, to shareholders, oriented by the expansion and combination of three types structure in family business: nuclear, extended and composed.

A notable fact in Menéndez family was the division of properties in 1911 through the Menéndez Behety Livestock and Commercial Corporation as successor of the José Menéndez \& Co., after to María Behety's death. The new society represented a type of family control that favored the durability of commercial livestock, maritime, mining and sawmill activities in Chile, and the control of shares by family members. After José Menéndez was death, all sons-in-law were added to the family company. According to the Anuario de Sucesos 1919-1920 published by E. Gómez \& Company $(1919,732)$ the firm’s board in 1918 included to Alejandro, José, Alfonso and Julio Menéndez-Behety, and Mauricio Braun (Josefina's husband), Arturo Gómez Palmés (Herminia's husband), and Francisco Campos (María's husband). In this way, the second generation of the Braun-Menéndez-Behety became part of La Anónima, merged it as the largest family business in the region. While the nuclear structure transformed in one of extended type. Before finishing his career in business, José Menéndez was a partner of the next formal companies: Sociedad Rural de Magallanes (1912), Industrial, and Livestock Society of Magallanes and Fishery Company of Magallanes (1914), and Insurance Company "La Austral" (1915). The final company was the last branch of the business family. Sara Braun remained active in business creating family-type businesses, especially in the branch of cattle; in 1914 she established the "Sara Braun" Livestock Corporation in Punta Arenas, as a nuclear family- 


\section{Journal of Evolutionary Studies in Business}

type company. ${ }^{14}$ The Society of Estancias "La Armonía" was one of those organized by Sara

Braun, although it was a composed family-type company, in which his brothers-in-law Alejandro and José Menéndez-Behety, as well as Casimiro Gómez were part of the board.

Figure 1. Total mercantile societies created by Mauricio Braun and José Menéndez (1875-1949)

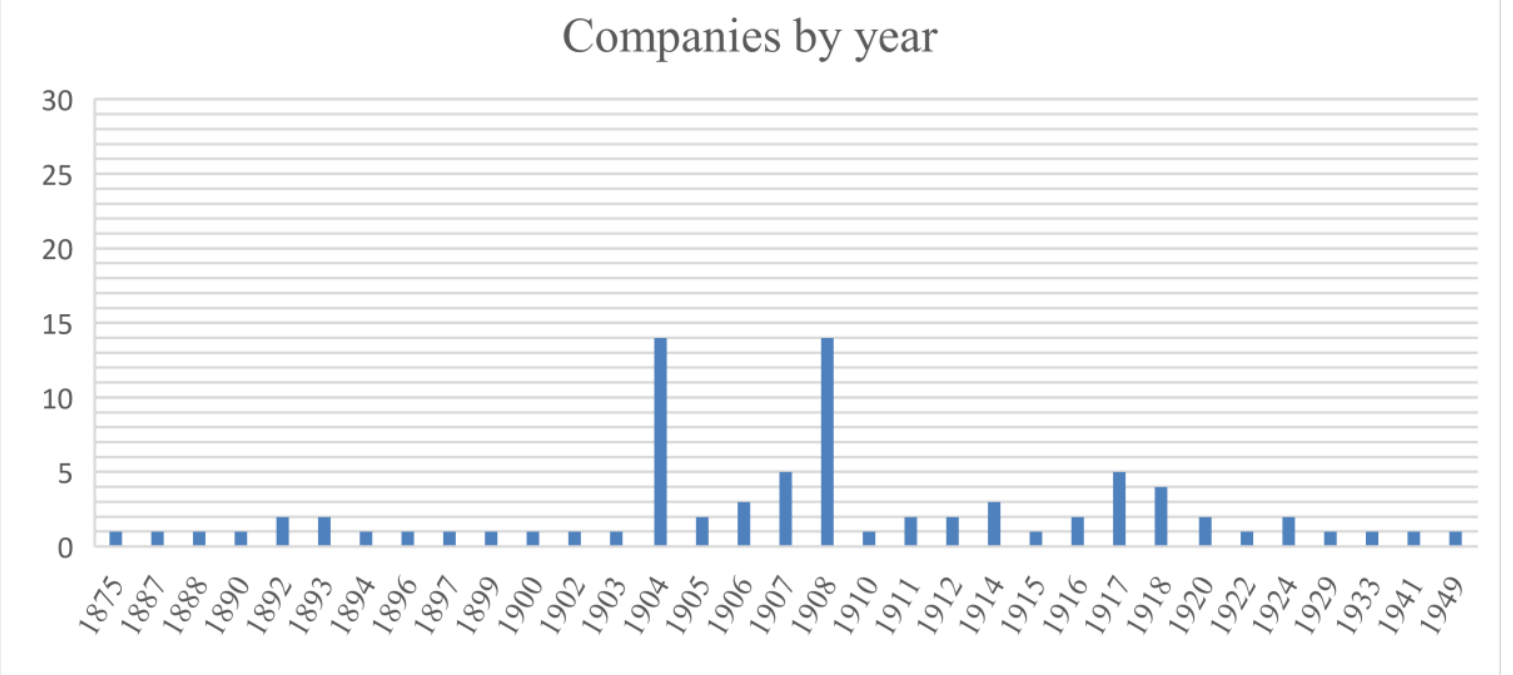

Source: Author's elaboration.

In summary, Mauricio Braun and José Menéndez took part in 82 companies (Figure 1), coinciding in 9 since 1897. And Mauricio Braun between 1904 and 1908, was part of founders and shareholder groups in 34 companies, in which 20 were based on Chile and 14 in Argentina. Those businessmen lived a key moment to enforce development of Southern Patagonia, becoming the pillars for next generations of business families and anonymous societies.

IV.2 Continuity of the Braun-Menéndez Behety family in Argentina and the firsts decades of a business family rooted to La Anónima

After the mergers of companies that gave life to La Anónima in 1908, Atlantic ports of Río Gallegos, Santa Cruz, San Julian, Comodoro Rivadavia and Puerto Madryn established the first

\footnotetext{
${ }^{14}$ The board included Elías Braun - father - and her brothers Mauricio, Oscar, Mayer and Juan (Ruffini 2017, 47).
} 
commercial subsidiaries. From there, the progressive penetration of this company in the Patagonian interior began with new offices that secured the supply of food and agricultural production, and acquisition of building materials. The success of La Anónima was teamwork and coordination, which had positive effects from the early stages. The company's capital increased 300 percent only in the first six years. When finish the first decade, La Anónima had increased its capital over 1,000 percent and had arrived at 30 establishments in the south of Argentine Patagonia functioning as matrixes or subsidiaries. The management functioning with a central, but each office had autonomy to solve own problems and decision making immediate, due to communication context of the time.

Although in 1914-1915 maritime traffic in the Magellan Port had serious problems when opening the Panama Canal provoking contraction in commercial flows, the World War I represented a new opportunity for primary merchandise trade to Patagonia. Then the region increased its presence in international wool markets and offering courier services. A big mistake was during the last years of World War, when bigger Patagonian producers starting a speculation of wool stocks, encourage by constantly growing of demand. Those actions caused indebtedness that extended when finished the bonanza period.

The due imposition of customs duties in Patagonia between the ending of 1918 and by1919, businesses in southern Chile had negative effects in cabotage routes, part, in shipments of meat and wool to Argentine and Chilean ports that had monopolized the freight handling. In $1920 \mathrm{La}$ Anónima experienced a reduction in the loans gotten by Argentine and Anglo-South American banks, so must explore domestic credit schemes and sales "to trust", as was usual. According to the expansionist policy in times of crisis, the members of the second generation agreed to 
establish in 1922 a second refrigerator named S. A. Cooperative Refrigeration Society of Puerto Deseado, being Alejandro Menéndez Behety and Mauricio Braun the CEOs.

La Anónima also installed another commercial agency in Buenos Aires dedicated to maritime affairs and purchases. In 1918, Argentine Federal Government granted legal status to the company. Then La Anónima turning into an Argentine company. The proprietary shareholders and general management moved to Buenos Aires, ${ }^{15}$ settling in a classic building of the Av. Roque Sáenz Peña, in the heart of City Porteña, which opened a new stage in the company's history and family Braun-Menéndez Behety, in coincidence José Menéndez death this year. In 1920 the situation did not improve because the livestock boom reversed. The fall of international currencies that came from wool and sheep meat affected La Anónima, leading to members of families to implement new changes. One of most important was the abolition of dividends from 1920. Was until 1928 that profits returned in $1.5 \%$; by 1931 were $3 \%$, but in 1932 back down to $2 \%$. The $10 \%$ paid between 1910-1919 never returned. Another effect of the wool market contraction to the constant exploitation of rural employees who were not organized and did not have any labor protection. ${ }^{16}$ The climate of rural conflicts in Chile and Argentina increased at the same time that the police severely repressed by police with the consent of farmers and merchants (Fisch 1933; Bayer 1972; Bonaudo and Bandieri 2000).

The Braun-Menéndez Behety family reacted to this crisis implementing organizational changes in La Anónima. Contrary to what we might think, at end of second decade of the 20th century, José Menéndez Jr. and Mauricio Braun carried out new investments and implement changes in

\footnotetext{
15 The build of new headquarters was inaugurated being director Mauricio Braun and Vice president Alejandro Menéndez Behety.

${ }^{16}$ The control of seasonal work has been possible due to large concentration of livestock and strong monopoly of trade, also the population had not labor alternatives.
} 
commercial strategy introducing a cooperative scheme. Headquarters and supply centers in Punta Arenas, and connection centers with England, Germany, Spain and other offices abroad, would be to import products to Patagonia and some products were acquired from northern Chile and nascent Argentine industry.

Members of the second generation of the Braun-Menéndez Behety family invested in vessels to control regional trade as it was in the past. In 1922 the company had four cargo ships and other 17 vessels. Likewise, shareholders approved the constitution of Public Limited Company, Argentine Refrigeration Company of Tierra del Fuego (1917) having the support of most important cattle farmers in southern Patagonia as shareholders. ${ }^{17}$ This was a modern refrigerator installed in the Port of Rio Grande to operate using a collective model and to benefit all investment farmers. The basis of family structure did not change although included no family members. ${ }^{18}$ The company consolidated in a short time. The first year the new company processing almost 150,000 animals and shipping 1,000 tons of meat sold in England markets. Other products sending to US were leather, tallow and visors.

By 1929 La Anónima already showed an excellent recovery; it had 10 commercial houses in the territory of Santa Cruz, 10 in Chubut and 3 in Río Negro, and as agencies in Magallanes Chile-, New York, London, Barcelona and Berlin, and an allowed capital of 20 million in sealed gold. ${ }^{19}$ As the regional crisis was overcome, the company also showed renewed economic vitality. Then were integrated the companies Astilleros Río de la Plata, Astarsa (naval, railway and road constructions branch), Austral (aerial branch and communication), Emecé (publishing

\footnotetext{
${ }^{17}$ The company had farms as anonymous shareholders to link more local people to rise exports.

${ }^{18}$ Alejandro Menéndez Behety was the President of board, Mayer Braun Vice president, and as directors Francisco Campos Torreblanca (son-in-law of José Menéndez) and José Montes Thurler. While Dr. Carlos Menéndez Behethy was a trustee.

${ }^{19}$ Revista Argentina Austral, 1929.
} 
industry), and other linked to insurance, financial, real estate, tourism, selling agricultural machinery and medical help services (Barbería 1995,71).

The company ships were part of fleet named Enosis -Greek word meaning "Union"-. It departed every month to southern seas loaded with the most varied merchandise to supply to La Anónima subsidiaries. Simultaneously, the firm worked as distributor of fruits, wool and meat, transported and banker offering replacement credits to primary production becoming (Jaca 1941 and 1968). Also, become to an active participant in community life of Patagonian localities. All collaborated to install electrical services, telephones, hospitals, schools, radio stations, airlines, etc. On June 10, 1933, La Anónima celebrated its first 25 years with the second generation in command. Also, the board included members of nuclear and extended family being the first time the members of third generation sharing in it. ${ }^{20}$

Next decades the family members of Braun-Menéndez Behety worked around mothercompany. In 1935, La Anónima incorporated the section of interoceanic agencies with regular routes to transfer of cargo and passengers to different continents. ${ }^{21}$ In response to the growth company were incorporated social activities to allow their employees (called "collaborators") feeling as part of "Enosis family". The vacations and entertainment for the firm's staff promoted trough company social clubs, and including the castle in Villa Elisa, at Buenos Aires. A scholarship system was also organized for the employees' children. La Anónima edited to its own advertising magazine named "Argentina Austral", published from 1929 to 1968 (Ruffini 2017). The goal to those years was each subsidiary supplied all items of a large general store,

\footnotetext{
${ }^{20}$ Mauricio Braun, Alfonso, Alejandro and Armando Braun Menéndez.

${ }^{21}$ In 1950s were constituted next companies: Austral Airlines (1957), it was the second commercial airline after Aerolineas Argentinas; later came the Chilean Interoceanic Navigation Company (1958) as a branch of Blanchard section; and the Maritime Company of Punta Arenas Anonymous Society in which a member of Menéndez Behety family was the CEO (1958).
} 
complemented with a skillful credit policy that allowed the company to keep its clientele secured.

In summarize, Mauricio Braun remained active and forming companies until 1949. He died in 1953 when family successors fully integrated La Anónima. The continuity to third generation will be analyzed in forward studies, for here is the evidence of continuity in international connections, and familiar strategies associated to successful succession. Extended nuclear and family ties were not only strategic for business continuity and learning, but for establishing a family corporate government visible in alternating positions in the directories. Mothercompanies since first stages experienced a vertical integration model, also with his own new suppliers to control production and distribution chains as in the past. The deepest crisis resolved to implement expansion and include practices to control markets and encourage the use of loyalty.

The original families of Braun and Menéndez Behety in Punta Arenas and their next generations exemplify a path towards settlement and internationalization at a stage in the evolution of capitalism that required significant supplies of raw materials and food. The first step was the settlement of families, the context of the transferring of land and the agreements between Chile and Argentina. After decades, studies on families who arrived after 1870s to Punta Arenas, started up more businesses in Argentina, this does not mean that Punta Arenas was more important than Tierra del Fuego or vice versa. They visualized a regional development encouraged commercial links with Europe and a new form to expand around the world very early in the 20th Century. This article reopens a discussion to global connections from LATAM. 


\section{Contributions to the study of inheritance, family businesses and business families}

The genealogical business reconstruction presented in this article offers evidence on European immigration in the accumulation process and the building of productive links in southern Patagonia. The institutional context was the "Colonization Laws" and agreements between Chile and Argentina on Austral Patagonian area. Consequently, the arrival of European groups improved schemes of learning as part of emergence of abroad commercial networks. They expose the permanence of families and constitution of family businesses with variations of global markets since middle of the19th Century. The first businesses were informal, through collective, and limited partnerships led by founders. The succession of Braun-Menéndez Behety groups with the company's local survival has observed in some business branch family and access to new activities like the refrigeration industry linked to livestock sector.

Adaptation and complex organizational systems processes were linked to business expansion. These show the trends of global economic demand in sheep meat derivate and its local impacts were technological and foreign linkages. As regards of abroad connections, the local families became in promoters and had commercial links with agents in England, France and Germany, and another one. In case of institutional frameworks, Patagonian families responded to foreign demand and influenced them. The local and national political and social alliances were as important as international trade networks to get permits and lands. The first groups endowed to resources to inhabit the Patagonian area, arrived and found natural resources used by indigenous groups to commerce mining and shipping sea services. The second productive embryo was the transport to enlarge regional accumulation based on exports and third the fridges.

First two generations of family business networks were built on friendship, marriages, and formal partnership. 1860s-1870s period complemented rapidly to nascent exploitation of 
breeder sheep in last decades of this century. People such as José Nogueira and members of Menéndez and Braun families, stand out by skills as visionaries and promoters of investments and introduces of technological tools, communications, lighting and banks. They implemented a rural management through innovative practices in livestock activities. The management and adaptation to local conditions produced the arrival of European technicians and technological changes which reinforcing the early accumulation process despite a double peripheral position of Patagonia in America and Europe. The built of commercial agencies, farm stays and the boat fleets are important evidences.

The land concession laws, started in the 1880s by Chile and Argentina, projected unique forms of transferences and collaboration between new settlers and European partners. The ways to get and enable land had at this moment diverse management win-to-win styles. The three business genealogies allow to distinguish: i) leadership to control the production value chains without intervention of intermediaries as local suppliers in part through Mother-companies, ii) absorption by co-participation of companies, iii) family partnership and friendship partner following formal agreements in associations and social enterprises, iv) introduction of figure of rural CEO, v) land brokers and formal land intermediaries, vi) accumulation of capital to reinvest by purchase and / or lease agreements post-grant with financial companies and individuals, vii) Productive diversification and new value chains associated to livestock.

The family member's successors of Braun's family managed since the early 20th Century some mother-companies: Braun \& Blanchard Co., SETF that included livestock, shipping and a commercial services, and the refrigeration industry, and La Anónima a merge of commercial branch of Braun and Menendez-Behety businesses and the most important to third and next generations whose members grew with it. 
After the expropriation of land to natives' groups and started official allocation of concessions, the immigrants should secure an efficient exploitation scheme. This goal led to the purchase of machinery and equipment for breeding, processing and packing of sheep products, and the hiring of pawns and specialized sheep-men. In the commercial and distribution chains ship fleets ensuring buyers in different countries. Mauricio Braun and José Menéndez controlled shipyards and machine repair shops to reduce maintenance costs and the family businesses help to control and reduce other transaction costs as negotiations vis-à-vis or signing of special agreements. Adding foreign partners as shareholders or buyers, the first and second-generation members supported the mutual learning and ensured future diversification of their commercial societies.

To understand the family continuity and survival of businesses, it needs family a researching of networking, for this reason, rebuilt three business genealogies. Families like Nogueira-Braun were disintegrating, and the heirs must take the control of continuity. Family disintegration by death can be a problem for survivors who have no commercial experience, so it can lose control. It can also be a problem when the family size is small. Fortunately, to business perdurability with Nogueira' firms, his widow had the support of her brother. And Mauricio that had been his brother-in-law's apprentice could ensure survival. In the Menéndez family, the second generation made lineage continuity possible through marriages. Meanwhile, the durability of the companies by the sons-in-law and the children who worked together and alternating positions in the family business directories. Intellectually, Maria Behety was a visionary by stipulating in her will the division of family actions and assets for business durability. And Sara Braun was a visionary when she relied on her brother to inherit the businesses of Nogueira. 
In summary, the business trajectories in the southern Patagonia between the end of 19th and the beginning of the 20th centuries conducing to argue that:

a) The friendship as a trust value to start a business in adverse conditions

b) The attorneys and concession land brokers and applicants as trustworthy individuals help to expand the relational capital of the petitioners

c) The Austral Patagonia area endorsed the interchanges of food and natural resources starting links abroad for the continuity of capitalism in LATAM

d) The financial accumulation of the first groups of immigrants established in Punta Arenas promoted takeoff and a productive control based on commercial, national and international alliances

e) The multiplication of some family companies was carried out controlling branches and suppliers in the value productive chains through different associations

f) The emergence of new agents and management practices in LATAM; in this case followed the specialization in sheep farming and increase in concessions

g) The crisis opened opportunities to family groups

h) The structure of the first family business is very important to understand the configuration of business families

i) The new generations started up family's business contributing to configurate a strong Braun business family

Business genealogies are elemental to business historians. They permitted to apply the biographic method, compile registers of companies, and personal information, as the Patagonian groups were addressed in this article. The study of family business and business families undoubtedly offer hints to debate about perdurability and continuity in business 
succession. The continuity of families is part of a socio-cultural process that imbricate to survival, learning (circulation of knowledge), trust and local economic development. The family business is an institutional structure as Veblen's arguments and is a receptive agent of institutional context as North argue. To study the family business composition in the long run, reinforce the importance of family environment in the building of capacities and businesses propagation. Finally, the business families configured upon to remoteness of Austral Patagonian between last decades of 19th and early 20th Centuries, as another in LATAM, are part of the capitalist history and they need to be more in debates and comparative analysis.

\section{References}

Almaraz, Araceli. 2018. "La empresa familiar y las familias empresariales en México. Una propuesta teórica." In Familias Empresariales en México, Sucesión generacional y continuidad en el siglo XX, coordinated by Araceli Almaraz, and Luis Alfonso Ramírez, 47-84. México: Colegio de la Frontera Norte, Second edition (on line).

Almaraz, Araceli, and Eloi Serrano. 2016. "Latin American Economic History, Business History and Economics of Enterprise: Current trends.” JESB, Journal of Evolutionary Studies in Business, 1(1): 95-115. doi: 10.1344/jesb2016.1.j006.

Bandieri, Susana, coord. 2001. Cruzando la Cordillera... La frontera argentino-chilena como espacio social. Neuquén, Argentina: Second edition EDUCO -Editorial Universitaria Universidad Nacional de Comahue. Serie Publicaciones CEHIR-UNCo.

Bandieri, Susana, coord. 2005. Cruzando la Cordillera... La frontera argentino chilena como espacio social. Neuquén: Argentina [Second ed.] EDUCO - Editorial Universitaria, Serie Publicaciones CEHIR-UNCo.

Bandieri, Susana. 2006. "Del discurso poblador a la praxis latifundista: La distribución de la tierra pública en la Patagonia Mundo Agrario. Revista de Estudios Rurales 6(11). https://www.mundoagrario.unlp.edu.ar/article/view/v06n11a01. 
Bandieri, Susana. 2013. "La frontera argentino-chilena como espacio social en la Patagonia: balance de una historiografía renovada." In Fronteras en movimiento e imaginarios geográficos. La Cordillera de los Andes como especialidad socio-cultural, edited by Andrés Núñez, Rafael Sánchez, and Federico Arenas, 67-88. Santiago de Chile: Instituto de Geografía de la Universidad Católica de Chile, Serie Geolibros, RIL Editores.

Bandieri, Susana 2015. "Inversión multiimplantada: tierras, comercio y finanzas en la Patagonia Austral." Revista Estudios del ISHIR 5(13): 20-40. http://revista.ishirconicet.gov.ar/ojs/index.php/revistaISHIR/article/view/574

Bandieri, Susana 2018. "El proceso de apropiación de tierras en la Patagonia Austral: la expansión de los grupos magallánicos.” In La tierra pública en la Patagonia. Normas, usos, actores sociales y tramas relacionales, edited by Graciela Blanco, 115-136. Rosario: Prohistoria.

Bandieri, Susana, and Graciela Blanco. 2009. "Política de tierras en los Territorios Nacionales: entre la norma y la práctica." In La cuestión de la tierra pública en Argentina. A 90 años de la obra de Miguel Angel Cárcano, coordinated by Graciela Blanco, and Guillermo Banzato, 163-199. Rosario: Prohistoria.

Barbería, Elsa. 1991. “Chile y Argentina. Una región autárquica en el sur, 1880-1920.” Waxen 5(4): 242.

Barbería, Elsa. 1994. "El Extremo Austral Sudamericano. Ocupación y Relaciones de los Territorios Argentinos y Chilenos (1880-1920).” Estudios Fronterizos 33:185-212.

Barbería, Elsa. 1995. Los dueños de la tierra en la Patagonia Austral, 1880-1920. Río Gallegos: Universidad Federal de la Patagonia Austral.

Barbero, María Inés, and Andrea Lluch. 2015. "El capitalismo familiar en Argentina: modelos y dinámicas en el largo plazo." In Familias empresarias y grandes empresas familiares en América Latina y España. Una visión de largo plazo, edited by Paloma Fernández Paloma and Andrea Lluch, 219-260. Bilbao: Fundación BBVA.

Bayer, Osvaldo. 1972. Los vengadores de la Patagonia trágica. Buenos Aires: Galerna, (1, 2, 3).

Bonaudo, Marta, and Susana Bandieri. 2000. "La cuestión agraria y la cuestión social desde la perspectiva regional." In Nueva Historia Argentina La sociedad de entreguerra 1916-1930 (I) directed by Ricardo Falcón. Vol. 6, 229-282. Buenos Aires: Editorial Sudamericana.

Cerutti, Mario 2015. “Grandes empresas y familias empresariales en México.” In Familias empresarias y grandes empresas familiares en América Latina y España. Una visión de largo plazo, edited by Paloma Fernández and Andrea Lluch, 153-188. Bilbao: Fundación BBVA. 
Coronato, Fernando. 2018. "De empleados a patrones. Ganaderos malvinenses en la Patagonia." In $\mathrm{La}$ tierra pública en la Patagonia. Normas, usos, actores sociales y tramas relacionales, edited by Graciela Blanco, 137-156. Rosario: Prohistoria.

Fernández-Roca, Francisco Javier, and Fernando Gutiérrez Hidalgo, eds. 2017. "New Perspectives in Family Business Research.” JESB, Journal of Evolutionary Studies in Business, 2(2): Special Issue.

Fernández Paloma, and Andrea Lluch, eds.. 2015. Familias empresarias y grandes empresas familiares en América Latina y España. Una visión de largo plazo. Bilbao: Fundación BBVA.

Fisch, Ricardo. 1933. "25 años de actividad económica a través de Memorias y Balances.” Revista Argentina Austral, 5(49): 37.

Gilbert, Jorge. 2003. "Entre la expansión y la crisis de la economía argentina. Ernesto Tornquist y Cia." Ciclos en la Historia, la Economía y la Sociedad 13(25-26): 65-92.

Gilbert, Jorge. 2009. "Redes sociales y vínculos familiares en los orígenes del grupo Tornquist.” Anuario CEEED 1:43-72.

E. Gómez \& Compañía. 1919. Anuario de Sucesos 1919-1920. Guía General de Chile, Informaciones generales de Comercio, Industria Importación, Exportación, Roles comerciales, Industriales y Profesionales, Año II. Valparaíso: E. Gómez, Editores.

Figueiras, Alberto José, and Hernán Alejandro Morero. 2013. "La teoría del consumo y de los ciclos en Thorstein Veblen." Revista de Economía Institucional, 15(28): 159-182.

Jaca, Juan Rodolfo. 1941. "La CAP adquirió el Frigorífico de Río Grande en T. del Fuego.” Revista Argentina Austral XIII (122): 17.

Jaca, Juan Rodolfo. 1968. "La actividad industrial de D. Alejandro Menéndez Behety.” Revista Argentina Austral, 434:14-19.

Lafuente, Horacio. 1996. "Los reyes de la Patagonia." Todo es Historia 350: 8-22.

Lafuente, Horacio. 2015. Tres reyes y una dama. Buenos Aires: Literarte.

López, Andrés. 2011. "Las empresas transnacionales en Argentina: del modelo agroexportador a las reformas estructurales." In El Impacto histórico de la globalización en Argentina y Chile: Empresas y Empresarios, edited by Geoffrey Jones, and Andrea Lluch, 101-131. Buenos Aires, Argentina: Editorial Temas.

Martinic Beros, Mateo. 1972. Magallanes, síntesis de tierra y gente. Buenos Aires, Argentina: F. de Aguirre.

Martinic Beros, Mateo. 1975. Las actividades iniciales de José Menéndez, 1875-1885. Punta Arenas, Chile: Instituto de la Patagonia, Serie Monográfica 8. 


\section{Journal of Evolutionary Studies in Business}

Martinic Beros, Mateo. 1976. "La expansión económica de Punta Arenas sobre los territorios argentinos de la Patagonia y Tierra del Fuego, 1885-1925.” Anales Instituto de la Patagonia 7:5-42.

Martinic Beros, Mateo. 2001a. "Patagonia Austral: 1885-1925. Un caso singular y temprano de integración regional autárquica." In Cruzando la Cordillera... La frontera argentino chilena como espacio social, coordinated by Susana Bandieri, 459-486. Neuquén: Argentina [Segunda edición] EDUCO -Editorial Universitaria, Serie Publicaciones CEHIR-UNCo.

Martinic Beros, Mateo. 2001b. Menéndez y Braun. Prohombres Patagónicos. Chile: Ediciones Universidad de Magallanes.

Martinic Beros, Mateo. 2001c. Nogueira el pionero. Punta Arenas: Ediciones Universidad de Magallanes.

Martinic Beros, Mateo. 2002. Breve Historia de Magallanes. Punta Arenas: Ediciones Universidad de Magallanes.

Moyano, Daniel 2015. Desde la empresa. Firmas familiares y estructura empresarial en la industria azucarera tucumana, 1895-1930. Buenos Aires: Prometeo Libros.

North, Douglass C. 1990. Institutions, Institutional changes and economic performance. Cambridge: Cambridge University Press.

Ruffini, Martha 2017. La Patagonia mirada desde arriba. El grupo Braun-Menéndez Behety y la Revista Argentina Austral (1929-1967). Rosario: Prohistoria.

Sociedad Anónima Importadora y Exportadora de la Patagonia. 1929. Revista Argentina Austral I (2).

Veblen, Thorstein. 1965. Teoría de la empresa de negocios. Buenos Aires: Eudeba. Originally published in English: Theory of business enterprise (New Brunswick: Transaction Books, 1904).

This is an Open Access article distributed under the terms of the Creative Commons Attribution-Non-Commercial-No Derivatives License (http://creativecommons.org/licenses/by-nc-nd/4.0/), which permits non-comercial re-use and distribution, provided the original work is properly cited, and is not altered or transformed in any way. 